\title{
HUBUNGAN KREATIVITAS DAN GAYA BELAJAR TERHADAP HASIL BELAJAR KOGNITIF BIOLOGI SMA
}

\author{
Ema Suryani \\ SMA Negeri 5 Metro \\ E-mail:emasukamto@gmail.com
}

\begin{abstract}
The study aims to study 1) the relationship of creativity to the cognitive learning outcomes of biology 2) the relationship of types of "learning style" to the cognitive learning outcomes biology 3) the relationship of creativity and leaming styles together to the biological cognitive learning outcomes. The research design uses correlational expost facto with quantitative approach. Sample 56 students. Creativity (X1) and visual, auditory, and kinesthetic (X2) learning styles (X2), and biological cognitive learning outcomes (Y) as dependent variables. Methods of data collection using closed questionnaire and rating with Likert scale. Performed content validation in the form of instrument grille. Correlation analysis techniques, simple regression and multiple regression, and partial correlation. Results of research 1) there is no significant relationship between creativity with biological cognitive learning outcomes. Shown with the value of r-count (0.113) $<$-table $(0,266) ; 2)$ there is no significant relationship between learning styles and biological cognitive learning outcomes. Shown with the value of $r$-count $(0,085)<$-table $(0,266)$. The dominant learning style of the students of Class XI IPA SMA N 5 Metro is visual number of learners 28 (50\%), auditorial 17 (30,36\%) learners and kinesthetic with number of learners 11 (19,64\%); (3) there is no influence between creativity and learning style on biological cognitive learning outcomes with $R 3=0.128$. Reinforced by seeing the Significance value of $0.266>$ from 0.05 .
\end{abstract}

Kata kunci: Kreativitas, Gaya Belajar, Hasil Belajar (kognit if)

Dari data Ujian Nasional Tahun Pelajaran 2014/2015, hasil belajar biologi peserta didik SMA N 5 mendapatkan nilai rata-rata tertinggi 77,06 dan nilai rata-rata terendah 30 . Sedangkan berdasarkan distribusi nilai UN SMA TP 2014/2015 peserta didik yang mendapatkan nilai di bawah rentang nilai 70 sebanyak 17 peserta didik. Kemudian dari hasil penilaian tengah semester ganjil mata pelajaran biologi di kelas XI IPA 4 SMA Negeri 5 Metro pada Tahun Pelajaran 2016/2017 bahwa dari peserta didik yang berjumlah 32 , ternyata yang mendapatkan nilai sesuai KKM sebanyak 50\% atau 16 peserta didik.

Salah satu indikator keberhasilan dalam pendidikan ini adalah terbangunnya generasi muda yang kreatif dan mandiri. Dikatakan berhasil jika generasi muda memiliki kemandirian dan kreativitas sehingga mampu bersaing di masyarakat dan dunia kerja. Karena dalam pendidikan formal peserta didik diajari bebagai macam skill dan pengetahuan yang akan merangsang daya kreatif yang ada dalam diri manusia yang secara alami terdapat dalam diri manusia.

Menurut Supriyadi

(1994)

Kreativitas adalah sebuah pemikiran 
yang divergen yaitu pemikiran yang dapat memberikan berbagai macam pernyataan dan pendapat. "Kreativitas tidak hanya dilakukan oleh orangorang yang memang pekerjaannya menuntut pemikiran kreatif (sebagai suatu profesi), tetapi juga dapat dilakukan oleh orang-orang biasa di dalam menyelesaikan tugas-tugas dan mengatasi masalah'.

Dalam keberhasilan belajar siswa tentu tidak terlepas dari gaya belajar dan sarana prasarana yang digunakan dalam proses pembelajaran seorang peserta didik. Di sekolah, sebagai pendidikan formal tentunya sudah memberikan berbagai sarana prasarana yang dianggap penting dalam proses pembelajaran di sekolah. Semua peserta didik mempunyai hak yang sama dalam menggunakan sarana yang telah disediakan sekolah untuk pembelajaran. Dengan demikian semua peserta didik mempunyai kesempatan untuk mendapat ilmu secara maksimal di sekolah. Namun hasil ketercapaian pembelajaran antara peserta didik satu dengan yang lainnya pasti tidak sama. Jika semua faktor eksternal dari siswa sudah terpenuhi secara merata maka, apa hal yang membuat hasil dari pencapaian peserta didik ini berbeda. Selain faktor eksternal terdapat faktor yang berasal dari diri sendiri. Dalam hal ini peserta didik mempunyai perbedaan dalam gaya belajar mereka. Mereka mempunyai kebiasaan yang berbeda dalam cara belajar. Selain dipengaruhi oleh kecerdasan dalam berpikir gaya belajar siswa sangat berpengaruh dalam keberhasilannya di kelas.

Kreativitas dan gaya belajar yang dipilih sebagai variabel yang diteliti, hal ini dikarenakan objek kajian yang dipelajari dalam biologi bersifat abstrak (fakta, konsep, operasi, prinsip), terdapat pemecahan masalah, serta adanya pengertian yang masih lemah dan belum bermakna dalam memahami konsep biologi. Sehingga peserta didik masih kesulitan dalam mempelajari biologi.

Berdasarkan latar belakang masalah dapat diidentifikasikan masalah sebagai berikut:

1. Masih rendahnya hasil belajar kognitif biologi peserta didik SMA N 5 Metro.

2. Tidak maksimalnya pekerjaan siswa karena siswa hanya mencontoh apa yang diajarkan guru tanpa melakukan modifikasi. Sedangkan seorang guru tidak akan memberi sebuah pengetahuan secara menyeluruh. Jika siswa tidak menggali ilmu secara mandiri maka ilmunya tidak akan melebihi gurunya. Sehingga perlu diberi kebebasan untuk mengembangkan skilnya.

3. Terdapat perbedaan karakteristik yang menyebabkan cara belajar tiap individu berbeda-beda.

4. Peserta didik masih berpikir secara konvergen sehingga apabila permasalahan yang dihadapinya agak berbeda penyajiannya mereka merasa kesulitan untuk menyelesaikannya. 
5. Terdapat peserta didik yang masih lemah dalam memahami pengertian konsep biologi. Sehingga peserta didik masih kesulitan dalam mempelajari biologi.

6. Sifat biologi yang abstrak menyebabkan kesulitan dalam mempelajarinya sehingga diperlukan suatu cara belajar tertentu sehingga kreatifitas peserta didik dapat terasah dengan baik

Sesuai dengan latar belakang masalah di atas, penelitian ini bertujuan untuk mengetahui:

1. Hubungan kreativitas terhadap hasil belajar kognitif biologi.

2. Hubungan jenis-jenis "gaya belajar" terhadap hasil belajar kognitif biologi.

3. Hubungan kreativitas dan gaya belajar secara bersama-sama terhadap hasil belajar kognitif biologi.

\section{METODE}

\section{Subjek Penelitian}

Penelitian ini dilakukan pada peserta didik di SMA N 5 Metro kelas XI IPA Tahun Pelajaran 2016/2017. Jumlah sampel yang digunakan dalam penelitian ini sebanyak 56 peserta didik yang diambil melalui teknik stratified random sampling.

\section{Variabel Penelitian}

$\left(\mathrm{X}_{1}\right) \quad$ Variabel Kreatifitas adalah perbuatan yang dilakukan pesera didik kelas XI SMA N 5 Metro pada materi sistem imun yang mencerminkan aspek a) kelancaran berfkir dalam mnyampaikan pendapat yang didapatkan dari proses belajar, b) keluwesan berfikir dalam menyampaikan berbagai pendapat dengan bervariasi, c) elaborasi, kemampuan mengembangkan idea atau pendapat yang dimilikinya d) originalitas yaitu kemamuan untuk menemukan sebuah gagasan baru dari dirinya sendiri bukan dari pendapat orang lain. Ditentukan dengan skor yang diperoleh dari peserta didik dalam mengisi angket kreativitas.

$\left(\mathrm{X}_{2}\right)$ Gaya Belajar memiliki tiga model Gaya Belajar visuals adalah cara digunakan peserta didik kelas XI SMA N 5 Metro pada materi sistem imun untuk belajar melalui gambar (symbol, grafik, diagram dan peta) yang mewakili apa yang disajikan kata-kata yang dilihat dari 1) belajar dengan mendeskripsikan gambar, 2) suka menggambar, 3) pandai mendeskripsikan gambar dan 4) mengingat dengan gambar.

Gaya Belajar Auditorial adalah cara digunakan peserta didik kelas XI SMA N 5 Metro pada materi sistem imun untuk belajar melalui apa yang didengar dan diucapkan yang diihat dari 1) belajar dengan cara mendengarkan, 2) lemah terhadap aktivitas visual, 3) peka terhadap music dan 4) baik dalam aktivitas lisan.

Gaya Belajar Kinesteticadalah cara digunakan peserta didik kelas XI SMA N 5 Metro pada materi sistem imun untuk belajar melalui pengalaman dan praktik yang dilihat dari 1) belajar dengan aktivitas fisik, 2) berorientasi fisik dan banyak bergerak, 3) peka terhadap ekspresi 
dan bahasa tubuh dan 4) suka kegiatan coba-coba. adalah skor yang diperoleh peserta didik dalam mengisi angket gaya belajar

(Y) Hasil Belajar Kognitif biologi adalah nilai yang diperoleh peserta didik yang diberikan oleh peneliti selama mengikuti pembelajaran biologi materi sistem imun. Ditentukan dengan nilai menggunakan hasil tes soal pilihan ganda.

Tabel I Teknik Pengumpulan Data

\begin{tabular}{|c|c|c|}
\hline Variabel & $\begin{array}{c}\text { Teknik } \\
\text { Pengumpulan } \\
\text { Data }\end{array}$ & $\begin{array}{c}\text { Subjek } \\
\text { Penelitian }\end{array}$ \\
\hline $\mathbf{X 1}$ & $\begin{array}{l}\text { Kuesioner } \\
\text { (angket) tertutup } \\
\text { dengan checklist }\end{array}$ & $\begin{array}{c}\text { Peserta } \\
\text { didik }\end{array}$ \\
\hline$\overline{X 2}$ & $\begin{array}{l}\text { Kuesioner } \\
\text { (angket) tertutup } \\
\text { dengan checklist }\end{array}$ & $\begin{array}{c}\text { Peserta } \\
\text { didik }\end{array}$ \\
\hline $\mathbf{Y}$ & Test pilihan ganda & $\begin{array}{c}\text { Peserta } \\
\text { didik }\end{array}$ \\
\hline
\end{tabular}

\section{Analisis Data}

Teknik analisis yang digunakan adalah korelasi, regresi sederhana dan regresi ganda, serta korelasi parsial.

\section{HASIL}

Berdasarkan acuan norma oleh Mardapi (2008:123), maka dapat dilakukan pengkategorian data kreativitas sebagai berikut.

Tabel 2 Hasil Kategori Kreativitas

\begin{tabular}{|l|l|c|c|}
\hline No & Kategori & Frekuensi & $\begin{array}{l}\text { Persentase } \\
(\boldsymbol{\%})\end{array}$ \\
\hline $\mathbf{1}$ & Tinggi & 9 & $16,07 \%$ \\
\hline $\mathbf{2}$ & Sedang & 32 & $57,14 \%$ \\
\hline $\mathbf{3}$ & Rendah & 15 & $26,79 \%$ \\
\hline & Total & 56 & $100 \%$ \\
\hline
\end{tabular}

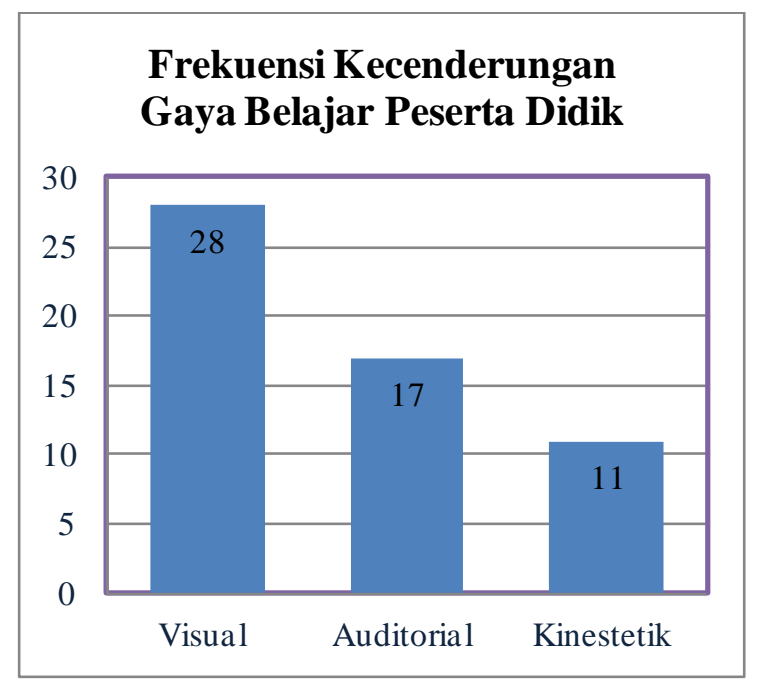

Gambar 1. Frekuensi Kecenderungan Gaya Belajar Peserta Didik

Berdasarkan acuan norma oleh Mardapi (2008:123), maka dapat dilakukan pengkategorian data hasil belajar kognitif biologi sebagai berikut.

Tabel3. Rumus Kategori Hasil Belajar Kognitif Biologi

\begin{tabular}{|l|l|l|}
\hline Kateg ori & \multicolumn{1}{|c|}{ Rumus } & \multicolumn{1}{c|}{ Skor } \\
\hline Tinggi & $\mathrm{X} \geq 71,5+3,83$ & $\mathrm{X} \geq 75,33$ \\
\hline Sedang & $71,5-3,83 \leq \mathrm{x}<$ & $67,67 \leq \mathrm{x}<$ \\
& $71,5+3,83$ & 75,33 \\
\hline Rendah & $\mathrm{X}<71,5-3,83$ & $\mathrm{X}<67,67$ \\
\hline
\end{tabular}

Tabel 4.Kategori Hasil Belajar Kognitif Biologi

\begin{tabular}{|l|l|c|c|}
\hline No & Kategori & Frekuensi & $\begin{array}{l}\text { Persentase } \\
(\boldsymbol{\%})\end{array}$ \\
\hline $\mathbf{1}$ & Tinggi & 31 & $55,36 \%$ \\
\hline $\mathbf{2}$ & Sedang & 19 & $33,93 \%$ \\
\hline $\mathbf{3}$ & Rendah & 6 & $10,71 \%$ \\
\hline & Total & 56 & $100 \%$ \\
\hline
\end{tabular}




\section{PEMBAHASAN}

Berdasarkan data penelitian yang telah dianalisis maka ringkasan hasil penelitian dapat diilustrasikan melalui gambar sebagai berikut.

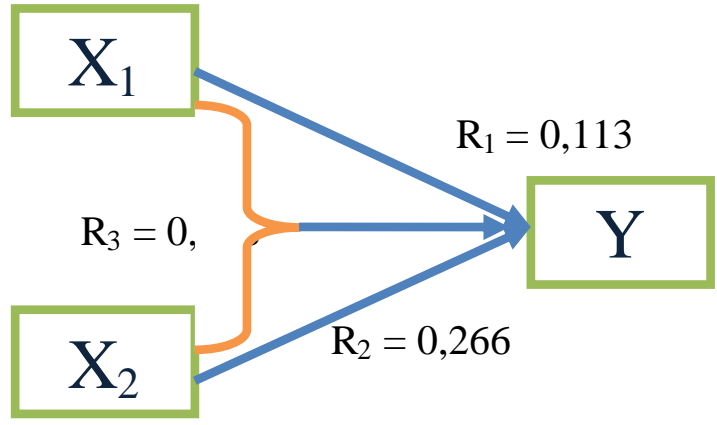

Gambar 2. Ringkasan Hasil Penelitian

Keterangan:

$\mathrm{X}_{1}=$ kreativitas

$\mathrm{X}_{2}=$ gaya belajar

$\mathrm{Y}=$ hasil belajar kognitif biologi

Tidak terdapat pengaruh antara kreativitas terhadap hasil belajar kognitif biologi. Pada jenisjenis gaya belajar dengan nilai $\mathrm{R}_{1}=$ 0,113 . Tidak ada pengaruh antara jenis-jenis gaya belajar terhadap hasil belajar kognitif biologi dengan nilai $\mathbf{R}_{2}=0,266$. Tidak ada pengaruh antara kreativitas dan gaya belajar terhadap hasil belajar kognitif biologi dengan nilai $R_{3}=0,128$. Masingmasing data menunjukkan nilai signifikansi $<0,05$.

\section{Pengaruh Kreativitas terhadap Hasil Belajar Kognitif Biologi}

Hasil penelitian yang telah dilakukan menunjukkan bahwa kreativitas peserta didik tidak mempunyai pengaruh yang positif dan signifikan terhadap hasil belajar kognitif biologi dengan nilai korelasi 0,113 .
Kreativitas dalam penelitian ini kurang pengaruhnya terhadap hasil belajar kognitif biologi. Berdasarkan pemaparan deskriptif variabel kreativitas dapat dilihat bahwa peserta didik SMA N 5 Metro mempunyai kreativitas sedang. Kemudian hal tersebut tidak sejalan dengan hasil belajar kognitif biologi yang dikerjakan oleh peserta didik. Berdasarkan deskriptif variabel hasil belajar kognitif biologi peserta didik SMA N 5 Metro mempunyai hasil belajar kognitif biologi tinggi. Dengan demikian kreativitas peserta didik tidak sebanding lurus dengan hasil belajar kognitif.

Tabel 5. Hubungan antara kreativitas dengan hasil belajar Kognitif Biologi

\begin{tabular}{|c|c|c|c|}
\hline \multicolumn{4}{|c|}{ Correlations } \\
\hline & & Kreativitas & $\begin{array}{c}\text { Hasil belajar } \\
\text { kognitif } \\
\text { biologi }\end{array}$ \\
\hline \multirow[t]{3}{*}{ Kreativitas } & $\begin{array}{l}\text { Pearson } \\
\text { correlation }\end{array}$ & 1 & .113 \\
\hline & $\begin{array}{l}\text { Sig. (1- } \\
\text { tailed) }\end{array}$ & & .204 \\
\hline & $\mathrm{N}$ & 56 & 56 \\
\hline \multirow{3}{*}{$\begin{array}{l}\text { Hasil } \\
\text { belajar } \\
\text { kognit if } \\
\text { biologi }\end{array}$} & $\begin{array}{l}\text { Pearson } \\
\text { correlation }\end{array}$ & .113 & 1 \\
\hline & $\begin{array}{l}\text { Sig. (1- } \\
\text { tailed) }\end{array}$ & .204 & \\
\hline & $\mathrm{N}$ & 56 & 56 \\
\hline
\end{tabular}

Hal ini tidak sejalan dengan pendapat oleh Munandar (2012: 47) bahwa kreativitas adalah sebagai kemampuan seseorang yang mencerminkan kelancaran, keluwesan, fleksibelitas dan keaslian dalam mengkolaborasi dan membuat sesuatu yang baru. Dalam penelitian ini adalah keterampilan peserta didik mengerjakan tes soal pilihan ganda materi sistem imun. Semakin tinggi nilai hasil belajar kognitif berarti 
peserta didik mempunyai kelancaran dalam mengerjakan tugas akhir, keluwesan dalam pelaksanaan hasil belajar kognitif biologi, fleksibel atau mau menerima hal baru.

Sedangkan menurut Supriyadi (1997: 7) bahwa kreativitas adalah kemampuan seseorang untuk melahirkan sesuatu yang baru baik berupa gagasan maupun hal nyata yang relative berbeda dengan yang lainnya atau hal yang pernah ada sebelumnya.

Dengan rendahnya kreativitas justru nilai hasil belajar kognitif biologi malah menjadi tinggi. Melihat pengaruh yang sangat kurang seharusnya kepala SMA N 5 Metro dapat selalu mengembangkan kreativitas peserta didiknya dengan cara selalu sering memonitoring kegiatan peserta didik baik dibidang akademik maupun nonakademik. Dengan demikian pihak sekolah/kepala sekolah dapat mengetahui kecenderungan peserta didiknya dalam hal akademik maupun nonakademik. Kepalas sekolah dibantu dengan guru pelajaran harus mampu memahami secara umum kecenderungan-kecenderungan peserta didiknya. Dengan mengetahui kebiasaan peserta didik diharapkan pihak sekolah dapat mefasilitasi apa yang dibutuhkan oleh peserta didik saat itu sehingga peserta didik dapat menggali potensi yang ada dalam dirinya.

Seorang guru juga tidak kalah penting perannya dalam pengembangan kreativitas peserta didik. Seorang guru harus mempunyai inovasi yang dapat dicontoh oleh peserta didik. Sebagai seorang yang paling dekat dengan peserta didik maka dapat dipastikan akan tahu apa yang paling dibutuhkan oleh peserta didik. Peserta didik yang mempunyai bakat tertentu seharusnya dapat diketahui oleh guru dan guru tersebut dapat merealisasikannya dengan cara pelatihan-pelatihan atau ekstrakulikuler yang berhubungan dengan pengembangan kreativitas. Bimbingan guru akan sangat bermanfaat bagi peserta didik baik bimbingan di sekolah maupun di luar sekolah.

Peserta didik dalam proses pembelajaran diharapkan mampu mengembangkan potensi dalam dirinya. Dalam penelitian ini agar peserta didik mendapat nilai hasil balajr kognitif biologi yang tinggi maka peserta didik setidaknya mempunyai kreativitas yang tingg juga kreativitas sesungguhnya dapat digali dan dikembangkan oleh individu. Untuk meningkatkan kreativitas, peserta didik harus berlatih sejak dini tentang apa saja yang menjadi indikator peserta didik yang kreatif, diantaranya adalah kelancaran berfikir, kelancaran berfikir tidak akan muncul dengan sendirinya tanpa ada latihan dan pengetahuan yang luas, keluwesan berfikir fleksibel dalam segala hal dan pengembangan diri. Semua itu tidak dapat didapat secara instan. Untuk mendapatkan semua itu harus dilatih dari sejak dini. Peserta didik harus mau membuka diri dari segala hal positif yang yang ada disekitarnya. Mau menggali ilmu dari guru, teman dan elemen pendidikan yang lain. 
Dengan banyak masukan maka akan banyak referensi yang bisa dikembangkan untuk menjadi sebuah hal baru yang muncul dari dalam dirinya.

Dari pernyataan-pernyataan angket yang diajukan kepada peserta didik. Menunjukkan belum adanya upaya yang maksimal untuk meningkatkan kreativitas bagi peserta didik. Upaya untuk meningkatkan kreativitas sangatlah perlu dilakukan agar terhindar dari hambatanhambatan dalam proses berkreativitas. Hambatan-hambatan yang mungkin terjadi dalam pengembangan setiap peserta didik, diantaranya: 1) kenakalan remaja, setiap peserta didik mempunyai sifat yang berbeda, ada yang mempunyai dampak negative ada pula yang negatif. Akan tetapi cenderung pada kenakalan peserta didik yang negatif, seperti mabukmabukan, merokok, berbohong. 2) takut terhadap kegagalan, kegagalan merupakan suatu yang menakutkan bagi peserta didik, karena setiap peserta didik yang sudah mengalami kegagalan pasti akan takut untuk mengulangi kembali sesuatu yang telah terjadi. 3) lingkungan yang tidak mendukung, lingkungan yang baik pasti akan membawa dampak baik bagi peserta didik, begitupula juga sebaliknya. 4) keadaan keluarga sangatlah mendukung suatu kreativitas peserta didik. Karena keluarga menjadi dasar pembentukan suatu kreativitas peserta didik. Jika keadaan keluarga kurang harmonis maka akan berdampak buruk bagi mental, kehidupan maupun kreativitas di masa mendatang.
Untuk itu perlu upaya-upaya yang dapat meningkatkan kreativitas, agar dapat menghindari hambatanhambatan dalam proses berkreatif. Caranya sebagai berikut:

1) Memelihara rasa ingin tahu. Keingintahuan disini adalah keingintahuan yang bisa dipertangungjawabkan. Misalnya berkaitan dengan materi penelitian yaitu tentang sistem imun. Rasa ingin tahu ini selanjutnya membawa peserta didik menemukan berbagai petunjuk untuk memelihara sistem kekebalan yang ada pada dirinya sendiri. Kreatifitas peserta didik pun meningkat karena telah memiliki kemampuan meningkatka n kemampuan dalam mempertahankan sistem imunitas.

2) Mencoba hal-hal baru. Kreativitas berkembang subur ketika peserta didik gemar mencoba hal-hal baru yang masing terasa asing. Orang sering enggan mencoba hal-hal baru karena sudah merasa nyaman dengan hal yang telah biasa dilakukannya. Hal yang sudah dilakukan dengan cara yang biasa tidak akan menambah pengalaman sehingga dengan sendirinya kreativitas kreativitas tidak akan meningkat.

3) Bersikap positif. Sikap negatif adalah sikap yang membunuh kreativitas. Bersikap positif berarti peserta didik bersedia terbuka gagasan-gagasan yang dilontarkan orang lain. Banyak orang menolak sebuah ide baru 
karena orang tersebut tidak cukup pengetahuan, tetapi menganggap dirinya sudah sukup tahu. Dengan pengetahuan yang terbatas, ia bersikap negatif terhadap ide-ide orang lain. Sebelum ada penolakan gagasan orang lain, pastikan dulu peserta didik tahu persis kualitas gagasan tersebut. Peserta didik harus mencobanya lebih dari satu kali sehingga tahu hasilnya.

4) Berani menghadapi resiko. Berani menghadapi resiko. Resiko adalah kejaian yang tidak kita harapkan terjadi karena ada konsekuensi yang harus kita tanggung. Kehidupan kita tidak pernah luput dari resiko. Benarlah pepatah yang mengatakan "tidak mengambil risiko pun merupakan suatu risiko". Jika peserta didik tidak bersedia menghadapi risiko yang berkaitan dengan kreativitas peserta didik. peserta didik akan menghadapi risiko lain, yakni kehilangan kreativitasnya. Jadi, dalam upaya meningkatkan kreativitas ada risiko yang kita hadapi.

Kreativitas bagi peserta didik sangatlah dibutuhkan karena kreativitas menjembatani peserta didik menuju masa depan yang lebih maju. Dengan kreativitas para peserta didik dapat mengembangkan kemampuannya untuk memahami pelajaran bilologi khususnya materi sistem imun.

Pengaruh Gaya Belajar "jenis-jenis gaya belajar" terhadap hasil belajar kognitif biologi.
Gaya belajar adalah variasi cara yang dimiliki seseorang untuk mengakumulasi serta mengasimilasi informasi. Pada dasarnya, gaya belajar Anda adalah metode yang terbaik memungkinkan Anda dalam mengumpulkan dan menggunakan pengetahuan secara spesifik. Kebanyakan ahli setuju bahwa ada tiga macam dasar gaya belajar. Setiap individu memungkinkan untuk memiliki satu macam gaya belajar atau dapat memiliki kombinasi dari gaya belajar yang berbeda.

Gaya belajar adalah kunci untuk mengembangkan kinerja dalam pekerjaan, di sekolah dan dalam situasi-situasi antar pribadi. Ketika kita menyadari bagaimana diri ini dan orang lain menyerap dan mengolah informasi, kita dapat menjadikan belajar dan berkomunikasi lebih mudah dengan gaya sendiri.

Ada dua kategori utama tentang bagaimana kita belajar yaitu:

a. Modalisme adalah bagaimana kita menyerap informasi dengan mudah

b. Dominasi otak adalah cara dan bagaimana kita mengatur dan mengolah informasi.

DePorter dan Hernacki (2000) mengemukakan tiga jenis gaya belajar berdasarkan modalitas yang digunakan individu dalam memproses informasi (perceptual modality). Ketiga gaya belajar tersebut adalah gaya belajar visual (belajar dengan cara melihat), auditorial (belajar dengan cara mendengar), dan kinestetik (belajar dengan cara bergerak, bekerja, dan menyentuh).

Setiap individu menggunakan semua indera dalam menyerap 
informasi. Tetapi, secara umum, individu mempunyai kecenderungan lebih kuat pada salah satu gaya belajar. Sebagian individu mudah menangkap informasi dalam bentuk visual, sebagian yang lain menyukai informasi bentuk verbal dan sebagian yang lain lebih nyaman dengan cara aktif dan interaktif.

Hasil penelitian yang dilakukan menunjukkan bahwa tidak terjadi pengaruh yang signifikan terhadap hasil belajar kognitif biologi. Pada penelitian didapat $r$ hitung lebih kecil dari $\mathrm{r}$ tabel, maka $\mathrm{H}_{0}$ diterima, dan $\mathrm{H}_{\mathrm{a}}$ ditolak. Tetapi sebaliknya bila $\mathrm{r}$ hitung lebih besar dari $\mathrm{r}$ tabel $\left(\mathrm{r}_{\mathrm{h}}>\right.$ $\mathrm{r}_{\text {tabel }}$ ) maka $\mathrm{H}_{\mathrm{a}}$ diterima. Ternyata $\mathrm{r}_{\text {hitung }}(0,085)$ lebih kecil dari $\mathrm{r}_{\text {tabel }}$ (0,266). Dengan demikian ketentuannya terima $\mathrm{H}_{\mathrm{O}}$, jadi tidak ada hubungan antara gaya belajar dengan hasil belajar kognitif biologi. Diperkuat dengan melihat nilai Signifikansinya $0,266>$ dari 0,05 , dapat ditarik kesimpulan terima $\mathrm{H}_{\mathrm{o}}$ dengan ketentuan tidak ada hubungan.

Tabel 6. Hubungan antara gaya belajar dengan hasil belajar kognitif biologi

\begin{tabular}{|l|l|l|l|}
\hline \multicolumn{2}{|c|}{ Correlations } & $\begin{array}{l}\text { Gaya } \\
\text { belajar }\end{array}$ & $\begin{array}{l}\text { Hasil } \\
\text { belajar } \\
\text { kognitif } \\
\text { biologi }\end{array}$ \\
\hline $\begin{array}{l}\text { Gaya } \\
\text { belajar }\end{array}$ & $\begin{array}{l}\text { Pearson } \\
\text { correlation }\end{array}$ & 1 & .085 \\
\cline { 2 - 4 } & Sig. (1-tailed) & & .266 \\
\cline { 2 - 4 } & $\mathrm{N}$ & 56 & 56 \\
\hline $\begin{array}{l}\text { Hasil } \\
\text { belajar } \\
\text { kognitif } \\
\text { biologi }\end{array}$ & $\begin{array}{l}\text { Pearson } \\
\text { correlation }\end{array}$ & .085 & 1 \\
\cline { 2 - 4 } & Sig. (1-tailed) & .266 & \\
\cline { 2 - 4 } & $\mathrm{N}$ & 56 & 56 \\
\hline
\end{tabular}

Hasil belajar kognitif yang baik pasti ditentukan oleh bagaimana proses belajar dia untuk menuju hasil yang baik pula. Proses atau gaya belajar pasti berbeda-beda dan masing-masing gaya belajar memiliki nilai positif dan negatif begitu juga dengan dampaknya kepada orang tersebut dan di sekelilingnya. Memang betul ada pola belajar yang tidak baik dan karena itu menghasilkan prestasi belajar yang buruk tetapi kalau pola belajar baik sudah dijamin mendapat hasil yang memuaskan. Mutu pendidikan pun juga mempengaruhi kelangsungan pola belajar seorang murid begitu juga dengan lingkungan murid tersebut. Tetapi yang paling mempengaruhi pola belajar terhadap hasil belajar adalah murid itu sendiri. Jika dia punya motivasi yang tinggi untuk mengembangkan pola belajar maka pola belajar tersebut akan membaik dan hasil hasilnya pun juga akan membaik. Gaya belajar dapat menentukan hasil belajar biologi peserta didik. Jika diberikan strategi yang sesuai dengan gaya belajarnya, anak dapat berkembang dengan lebih baik. Gaya belajar otomatis tergantung dari orang yang belajar. Artinya, setiap orang mempunyai gaya belajar yang berbeda-beda.

Rahasia keberhasilan pembelajaran terletak pada pengenalan seseorang terhadap dirinya sendiri, kesesuaian gaya mengajar dan gaya belajar, potensinya, dan konsekwensi yang ditimbulkannya. Pengalaman di Swedia dan Selandia Baru, sekolah yang telah menerapkan gaya belajar menunjukkan perubahan, antara lain; disiplin membaik, prestasi akademik meningkat, kerjasama staf juga lebih 
baik, komunikasi lebih lancar, minat orang tua dalam pembelajaran meningkat. Kenyataannya, hampir semua murid yang berprestasi rendah adalah murid yang gaya belajarnya tidak cocok dengan gaya mengajar guru di sekolah dan berdasar penelitian dapat dipaparkan dari keseluruhan jumlah peserta didik dengan kecenderungannya masingmasing, yaitu sebagai berikut: terdapat 28 peserta didik dengan kecenderungan gaya belajar visual, 17 peserta didik dengan kecenderungan gaya belajar auditorial dan 11 peserta didik dengan kecenderungan gaya belajar kinesthetic. Sedangkan rerata skor dari masing-masing gaya belajar adalah 26,84 untuk gaya belajar visual untuk gaya belajar auditorial dan 25,68 dan 24,73 untuk gaya belajar kinesthetic. Sehingga pada penelitian ini gaya belajar visual yang mempunyai kecenderungan hasil belajar kognitif lebih tinggi, gaya belajar auditorial berada diurutan kedua dan yang paling sedikit adalah gaya belajar kinesthetic.

Hal ini sesuai dengan pendapat DePorter dan Hernacki (2000) dalam bukunya quantum learning kecenderungan gaya belajar visual lebih senang melihat apa yang sedang dipelajari. Gambar/visualisasi akan membantu mereka yang memiliki gaya belajar visual untuk lebih memahami ide atau informasi daripada apabila ide atau informasi tersebut disajikan dalam bentuk penjelasan. Apabila seseorang menjelaskan sesuatu kepada orang yang memiliki kecenderungan gaya belajar visual, mereka akan menciptakan gambaran mental tentang apa yang dijelaskan oleh orang tersebut. Ciri-ciri gaya belajar visual :

a. Bicara agak cepat

b. Mementingkan penampilan dalam berpakaian/presentasi

c. Tidak mudah terganggu oleh keributan

d. Mengingat yang dilihat, dari pada yang didengar

e. Lebih suka membaca dari pada dibacakan

f. Pembaca cepat dan tekun

g. Seringkali mengetahui apa yang harus dikatakan, tapi tidak pandai memilih kata-kata

h. Lebih suka melakukan demonstrasi dari pada pidato

i. Lebih suka musik dari pada seni

j. Mempunyai masalah untuk mengingat instruksi verbal kecuali jika ditulis, dan seringkali minta bantuan orang untuk mengulanginya.

Melihat kecenderungan gaya belajar peserta didik di SMA N 5 Metro, kepala sekolah seharusnya memperhatikan perbedaan individu tersebut. Perbedaan itu akan digunakan sebagai acuan untuk perlakuan setiap individu satu dengan individu yang lainnya. Dalam penelitian ini akan diteliti tentang gaya belajar yang berpengaruh terhadap hasil tugas akhir. Seorang kepala sekolah diharapkan mengetahui kecenderungan gaya belajar apa yang paling cocok dalam sebuah pembelajaran. Untuk mengetahui kecenderungan gaya belajar peserta didik kepala sekolah harus sering memonitoring aktivitas 
peserta didik dengan bantuan guru maupun peserta didik sendiri. Setelah tahu kecenderungan gaya belajar peserta didik diharapkan pihak sekolah atau kepala sekolah dapat menyikapi perbedaan individu tersebut sehingga proses pembelajaran peserta didik dapat berjalan dengan lancar.

Seorang guru wajib mengetahui kecenderungan gaya belajar peserta didiknya. Karena dalam kelas seorang guru tidak boleh memberi perlakuan yang sama antara individu satu dengan individu yang lainnya. Seorang guru harus mampu membedakan kebutuhan peserta didik masing-masing. Setelah mengetahui kecenderungan gaya belajar peserta didiknya maka seorang guru akan mengetahui bagaimana metode yang tepat untuk menangani peserta didik dengan kecenderungannya masingmasing agar penyerapan materi oleh peserta didik bisa maksimal.

Strategi untuk mempermudah proses belajar anak visual :

Gunakan materi visual seperti, gambar-gambar, diagram dan peta.

a. Gunakan warna untuk menghilite hal-hal penting.

b. Ajak anak untuk membaca bukubuku berilustrasi.

c. Gunakan multi-media (contohnya: komputer dan video).

d. Ajak anak untuk mencoba mengilustrasikan ide-idenya ke dalam gambar.

Peserta didik yang mempunyai kecenderungan gaya belajar visual, auditorial maupun kinesthetic harus tetap belajar sesuai dengan kecenderungannya masing- masing. Setiap peserta didik pada dasarnya mempunyai semua jenis gaya belajar namun hanya ada satu yang dominan. Setelah mengetahui jenis gaya belajar yang dominan pada dirinya, peserta didik harus menggali potensinya dengan gaya belajar yang dominan tersebut. Karena dalam penelitian ini, dijelaskan bahwa gaya belajar yang dominan pada seseorang entah gaya belajar visual, auditorial dan kinesthetic adalah cara yang tepat digunakan untuk menyerap materi secara efektif dan efisien.

Dampak gaya belajar kepada pendidikan secara umum terkait dengan apa yang harus dilakukan guru terhadap materi pembelajaran (kurikulum), pengajaran, dan penilaian sebagai tolak ukur keberhasilan pembelajaran. Guru harus memperhatikan kesesuaian antara metode pengajaran dengan gaya belajar. Guru wajib menganali gaya belajar setiap pesert didiknya kemudian dilihat mana gaya belajar yang paling dominan, hal itulah yang harus disesuaikan dengan metode pengajarannya. Walaupun kelompok minoritas dari gaya belajar tidak dapat menyesuaikan gaya belajarnya dengan yang lain diharapkan bisa mengikuti gaya belajar peserta didik yang lain dan guru bisa menerapkan semua metode pembelajran yang tetap membuat anak merasa nyaman dengan gaya belajarnya. Peranan guru harus tetap dijaga.

a. Kurikulum: guru harus memberikan penekanan kepada intuisi, perasaan, pengindraan, dan imajinasi peserta didik sebagai pelengkap dari 
peningkatan keterampilan tradisional seperti menganalisis, menalar, dan memecahkan masalah secara urut.

b. Pengajaran: guru wajib merencanakan metode pembelajarannya sesuai dengan berbagai gaya belajar siswa, menggunakan berbagai kombinasi seperti pengalaman, refleksi, konseptualisasi, dan eksperimentasi. Guru dapat memperkenalkan berbagai unsur pengalaman kedalam kelas misalnya dengan bunyi-bunyian, music, gambar visual, gerakangerakan, pengalaman dan bahkan percakapan.

c. Penilaian: guru wajib menerapkan berbagai teknik penilaian yang berfokus kepada pengembangan kapasitas totalitas otak dan berbagai gaya belajar yang berbeda-beda. Dalam tes bahasa misalnya di samping digunakan tes tulis juga tes lisan serta listening comprehension.

\section{KESIMPULAN}

Berdasarkan perhitungan, analisis dan pembahasan terhadap masalah penelitian sebagaimana disajikan pada Bab IV, penulis mengambil kesimpulan sebagai berikut:

1. Jawaban hipotesis pertama ternyata $r_{\text {hitung }}(0,113)$ lebih kecil dari $r_{\text {tabel }}(0,266)$. Dengan demikian ketentuannya terima $\mathrm{H}_{\mathrm{O}}$, jadi tidak ada hubungan antara kreativitas dengan hasil belajar kognitif biologi. Hasil tersebut dapat disebabkan oleh persebaran tingkat kreatifitas peserta didik. Diketahui bahwa sebagian besar peserta didik kelas XI SMA N 5 Metro Tahun Pelajaran 2016/2017 pada tingkatan sedang $(57,14 \%)$.

2. Jawaban hipotesis kedua ternyata $\mathrm{r}_{\text {hitung }}(0,085)$ lebih kecil dari $\mathbf{r}_{\text {tabel }}$ $(0,266)$. Dengan demikian ketentuannya terima $\mathrm{H}_{\mathrm{O}}$, jadi tidak ada hubungan antara gaya belajar dengan hasil belajar kognitif biologi.

Sedangkan untuk gaya belajar yang dominan dari peserta didik Kelas XI IPA SMA N 5 METRO yaitu gaya belajar visual dengan jumlah peserta didik 28 (50\%). Sedangkan untuk gaya belajar auditorial dengan jumlah peserta didik 17 (30,36\%). Selanjutnya untuk gaya belajar kinestetik dengan jumlah peserta didik 11 $(19,64 \%)$.

3. Jawaban hipotesis ketiga diperkuat dengan melihat nilai Signifikansinya 0,266 > dari 0,05, dapat ditarik kesimpulan terima $\mathrm{H}_{\mathrm{o}}$ dengan ketentuan tidak ada hubungan. Tidak ada pengaruh antara kreativitas dan gaya belajar terhadap hasil belajar kognitif biologi dengan nilai $\mathrm{R}_{3}=0,128$. Walaupun kategori hasil belajar kognitif biologi tinggi dengan frekuensi 31 peserta didik $(55,36 \%)$, kategori sedang dengan frekuensi 19 peserta didik $(33,93 \%)$, kemudian kategori rendah dengan frekuensi 6 peserta $\operatorname{didik}(10,71 \%)$.

\section{DAFTAR RUJUKAN}


DePorter, Bobbi \& Mike, Hernacki. 2000. Quantum Learning. Edisi Revisi. Bandung: Kaifa.

Mardapi, Djemari (2008). Teknik

Penyusunan Instrumen Tes dan Non

Tes. Yogyakarta: Mitra Cendekia

Munandar S.C, Utami. 1999.

Kreativitas dan Keberbakatan.

Jakarta: PT Gramedia Pustaka Utama.

Supriyadi, Dedi. 1997. Kreativitas,

Kebudayaan, dan

Perkembangan Iptek. Bandung:

CV Alfabeta. 